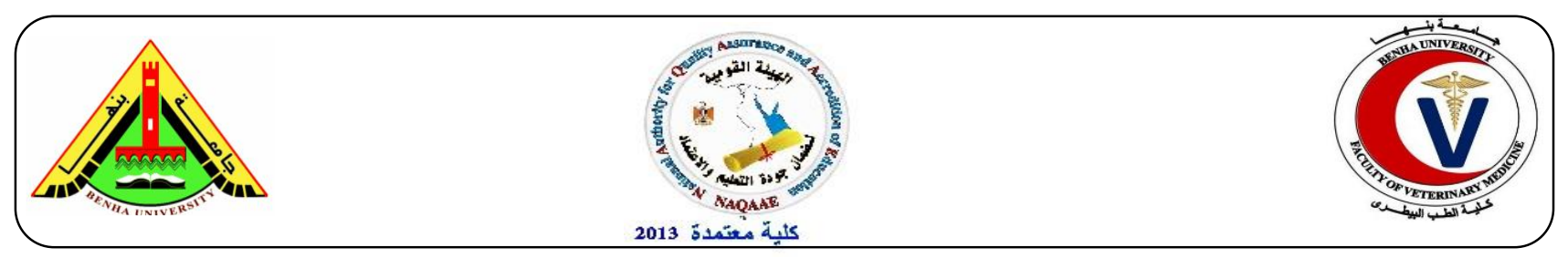

\title{
Evaluation of Hepatoprotective Impact of Ginger Extract Against Paracetamol- Induced Hepatotoxicity in Albino Rats
}

\author{
Abd El Fadil H. ${ }^{1}$, Edress N. ${ }^{1}$, Khorshid N. ${ }^{2}$ and Amin N. ${ }^{3}$ \\ ${ }^{1}$ Pharmacology Dept., Fac. Vet. Med., Zagazig University, Egypt. \\ ${ }^{2}$ Pharmacology Dept., Fac. Medicine, Zagazig University, Egypt. \\ ${ }^{3}$ Directorate of Veterinary Medicine, Zagazig, Egypt.
}

\begin{abstract}
A B S T R A C T
The study was designed to assess the antioxidant and the hepatoprotective impact of ginger against paracetamol-induced liver damage in male albino rats. Rats were partitioned into six equal groups $(\mathrm{n}=5)$. Control group rats were given normal saline $(1 \mathrm{ml} / \mathrm{kg} \mathrm{b} . \mathrm{wt})$ for 15 days orally by stomach tube. Silymarin group rats were orally adminstered silymarin $(200 \mathrm{mg} / \mathrm{kg}$ b.wt) by stomach tube for 15 days. Ginger group rats were received ginger extract $(200 \mathrm{mg} / \mathrm{kg}$ b.wt) orally by stomach tube for 15 days. Paracetamol group rats were given paracetamol orally $(500 \mathrm{mg} / \mathrm{kg} \mathrm{b.wt}$ ) by stomach tube for the last five days of the experiment. Silymarin + paracetamol group rats orally pretreated with silymarin for ten days followed by silymarin with paracetamol simultaneously for the last five days and lastly ginger + paracetamol group rats orally received ginger for ten days followed by ginger simultaneously with paracetamol for the last five days. On the $16^{\text {th }}$ day of investigation, the animals sacrificed, serum and liver tissues were preserved for measuring the activities of liver enzymes, beside the levels of total bilirubin, tumor necrosis factor-alpha (TNF- $\alpha$ ), lactate dehydrogenase activity (LDH) and hepatic oxidant/antioxidant status. The liver injury initiated by paracetamol manifested by significant increase in liver marker enzymes including alanine aminotransferase (ALT) and aspartate aminotransferase (AST) also it produced a significant increase in serum total bilirubin, TNF- $\alpha$ level and LDH enzyme activity. Malondialdehyde (MDA) concentration was significantly increased in liver tissue of rats received paracetamol, while the concentration of catalase (CAT), superoxide dismutase (SOD) and glutathione peroxidase (GPx) were significantly decreased. The alteration in all previous parameters was modified by pretreatment with silymarin and ginger. Histopathological examination of liver induced disturbed liver functions in paracetamol treated rats but restored to nearly normal picture by pretreatment with silymarin and ginger. The findings proved that the administration of ginger improved the hepatotoxic effect of paracetamol in rats.
\end{abstract}

Key words: Paracetamol, Hepatotoxicity, Ginger, Silymarin, rats.

(http://www.bvmj.bu.edu.eg)

(BVMJ-35(2): 302-316, 2018)

\section{INTRODUCTION}

The liver is greatly important organ for regulation of body homeostasis. It keeps up

different biochemical pathways controlling body development, protect from certain 
disorders and support production of energy (Rajkiran et al., 2015). Nowadays, researches focus mainly on trying to find and evaluate different hepatoprotective agents against damage produced hepatotoxic agents (Shanmugasundaram and Venkataraman, 2006).

Paracetamol (PCM) is an excellent antipyretic and analgesic drug and is proven safe when taken in therapeutic doses, however overdose can causes hepatotoxicity (Larson, 2007). Paracetamol induced toxicity in animals is one of the most commonly experimental model to evaluate the hepatoprotective activity (Jayadevaiah et al., 2012).

The side effects of paracetamol intoxication were acute liver failure, necrosis or renal tubules and hypoglycaemic coma (Lancaster et al., 2015). Paracetamol hepatotoxicity results by the reaction of metabolite $\mathrm{N}$ acetyl-pbenzoquinoneimine (NAPQI), which induced oxidative stress and glutathione reduction (Mandade, 2011).

Silymarin, a liver protective agent flavonoid complex including silymarin, isosilybinin, silidianin and silychristin, segregated from the seeds of Silynum marianum (milk thistle) possesses a powerful free radical searching properties (El-Shitanya et al., 2008). Silymarin can be utilized as hepatoprotective/ hepatic regenerator, immunomodulator, antioxidant and anti-inflammatory (Elmowafy et al., 2013). Silymarin likewise animates RNA and protein synthesis leading to prompting quicker recovery, repair and renovation after liver and kidney damage (Patel et al., 2010).

The great potential of plant-derived natural antioxidants in health promotion, disease hindering and improved consumer safety and acceptance make it better than synthetic antioxidants (Gulcin, 2006).

Ginger is an underground rhizomes of plant Zingiber officinale belonged to the family Zinghberaceae which is widely consumed as spice for the flavoring of foods (Ajith et al.,
2007). Preclinical examinations completed with laboratory animals have likewise demonstrated that ginger to have hepatoprotective impacts, and to secure the liver against the lethal impact of heavy metals (Khaki, 2010). All ginger's significant dynamic ingradients, such as Zingerone, gingerdiol, Zingiberene, gingerols and Shogaols, are known to have antioxidant activities (Zancan et al., 2002). The study aimed to explore the essential impact of ginger against acute liver damage induced by paracetamol in male albino rats.

\section{MATERIALS AND METHODS}

\subsubsection{Medicinal plant}

The ginger was gathered from neighborhood market and cut into little pieces and dried under ceiling fan for 5 to 6 days. The dried ginger was ground in an electronic processor and powder was gathered. $50 \mathrm{~g}$ of powder was dissolved in $250 \mathrm{ml}$ ethanol for 18 hours in Soxhlet apparatus. The concentrate was dried at reduced pressure, stored at $0-4^{\circ} \mathrm{C}$ and utilized for the experimentation (Sekhar et al., 2005).

Ginger extract was orally given in a dose of (200 mg/kg b.wt) (Ajith et al., 2007).

\subsubsection{Chemicals:}

Silymarin (Livamarin)®: Sachets $(140 \mathrm{mg})$ was obtained from European Egyptian Pharmaceutical Company, Egypt. It is orally given in a dose of $(200 \mathrm{mg} / \mathrm{kg}$ b.wt.) (Kanchanai and Sadiq, 2011)

Paracetamol (Panadol)®: Tablets (500 mg) received from Glaxo Smithkine, Dungarvan Ltd. Company, Ireland and orally given in a dose $500 \mathrm{mg} / \mathrm{kg}$ b.wt (Farghaly and Hussein, 2010).

\subsubsection{Experimental animals}

Thirty male albino rats $(200 \pm 10 \mathrm{~g})$ were prepared for this experiment. They were brought from the Laboratory Animal Unit, Faculty of Veterinary Medicine, Zagazig University, Egypt. They were held still in the laboratory environment for one week before 
use. The animals were held in stainless steel cages, kept in $12 \mathrm{hr}$ light-dark cycle at an optimum temperature $\left(21\right.$ to $24^{\circ} \mathrm{C}$ ), and were given slandered diet and water ad-libitum. The care and walfare of the rats confirmed to the roles of the animal use Research Ethics Committee of Faculty of Veterinary Medicine, Zagazig University, Egypt.

\subsection{Methods}

\subsubsection{Experimental design}

Male albino rats (thirty) were allocated into six equivalent groups, every one of five rats. Control group rats given physiological saline ( $1 \mathrm{ml} / \mathrm{kg}$ b.wt) for 15 consecutive days. Silymarin group rats were orally given silymarin (200 mg/kg b.wt) for 15 progressive days. Ginger treated rats were orally given ginger $(200 \mathrm{mg} / \mathrm{kg}$ b.wt) for 15 days. Paracetamol group rats were orally given paracetamol $(500 \mathrm{mg} / \mathrm{kg} \mathrm{b.wt})$ or the last 5 progressive days. Silymarin + paracetamol group rats pretreated with silymarin for 10 days followed by silymarin administration together with paracetamol for the last 5 progressive days and lastly ginger + paracetamol group rats pretreated with ginger for 10 progressive days followed by ginger administration simultaneously with paracetamol for the last 5 progressive days.

\subsubsection{Sampling}

\section{a) Blood samples}

After finishing experimental treatment, animals were fasted overnight then killed under light anaesthesia by ether. Blood was collected from five rats from each group into a sterile centrifuge tube and centrifuged at $3000 \mathrm{rpm}$ for 10 minutes to separate serum for further biochemical analysis.

b) Liver tissue hemogenate

Part of the liver was collected quickly after decapitation of animals under light anaesthesis then washed with ordinary physiological saline for oxidative stress assessment. By using an electrical homogenizer a $0.5 \mathrm{~g}$ of liver tissue was homogenized in $5 \mathrm{ml}$ phosphate buffer saline $(7.4 \mathrm{pH})$ and keeping the samples on ice, then centrifugation of tissue homogenates at 1200 $\mathrm{rpm}$ for $20 \mathrm{~min}$. at $4^{\circ} \mathrm{C}$, finally the supernatants were isolated and stored at $-80^{\circ} \mathrm{C}$ until further use in assessment of antioxidant and oxidative stress biomarkers. The second part was fixed in neutral formalin $10 \%$ for histopathological examination.

\subsubsection{Biochemical analysis}

Liver enzyme activities such as ALT AST were determined (Reitman and Frankel, 1957). Serum ALP was determined (Moss, 1982). Serum total bilirubin was determined (Doumas et al., 1973). Serum tumor-necrosis factor alpha (TNF- $\alpha$ ) was done by ELISA (Corti et al., 1992) and serum LDH activity was determined (Siekman et al., 2002).

\subsubsection{Antioxidant/oxidant status}

The antioxidant enzymes as CAT was determined (Aebi, 1984) SOD was determined (Nishikimi et al., 1972) and GPX was determined (Paglia and Valentine, 1967) While MDA levels was determined (Satoh, 1978 and Ohkawa et al., 1979)

\subsubsection{Histopathological examination}

Specimens from liver were taken for histopathological examination and fixed in $10 \%$ neutral buffer formalin, paraffin sections of 5 micron thickness were prepared, stained with H\&E stain then examined microscopically (Bancroft and Gamble, 2013).

\subsubsection{Statistical analysis}

The results were represented as mean \pm SE for each group. the difference between groups were statistically and analyzed using one-way analysis of variance (ANOVA) SPSS.16 followed by Duncan's multiple range post hot test for pair wise comparisons. Data were considered significant at $\mathrm{P}<0.05$ (Tamhane and Dunlop 2000). 


\section{RESULTS}

\subsection{Serum biochemical results}

3.1.1. Liver enzyme activities and total bilirubin

Non significant variations were recorded in liver enzymes post administration of silymarin and ginger, while the rats orally administered paracetamol demonstrated a significant rise $(\mathrm{P}<0.05)$ in ALT, AST activities and total bilirubin level comparing with control group. The rats pretreatment with silymarin or ginger then given silymarin or ginger

simultaneously with paracetamol showed a significant decline in enzymes activities (ALT and AST) and total bilirubin level when compared with paracetamol group (Table 1).

3.1.2. Tumor necrosis factor-alpha (TNF- $\alpha$ ) and lactate dehydrogenase activity (LDH) The experimental rats orally given silymarin and ginger evoked non significant change in TNF- $\alpha$ and LDH activity comparing with control gathering. A significant rise $(\mathrm{P}<0.05)$ in serum TNF- $\alpha$ level and LDH activity was noticed in rats orally received paracetamol when compared with control group. pretreatment of rats with silymarin or ginger followed by silymarin or ginger simultaneously with paracetamol elicited a significant decrease in TNF- $\alpha$ level and LDH activity comparing with paracetamol group (Table 2).

\subsection{Oxidative/antioxidant status}

The current data showed non significant change in the concentration of MDA concentration and activities of CAT, SOD and GPX enzymes in groups received silymarin and ginger when compared with control group. While the experimental rats in the paracetamol group indicated a critical elevation $(\mathrm{P}<0.05)$ in MDA concentration with a considerable reduction $(\mathrm{P}<0.05)$ in CAT, SOD and GPX enzymes comparing with control group. Likewise, when silymarin or ginger given prior and simultaneously with paracetamol revealed a significant decrease $(\mathrm{P}<0.05)$ in MDA concentration with a significant elevation $(\mathrm{P}<$ 0.05) in CAT, SOD and GPX enzymes comparing with paracetamol group (Table 3).

3.3. Histopathological findings in liver Control, silymarin and ginger groups showed normal hepatic histomorphology but in paracetamol treated group, there was distoration of liver architecture, there was also focal necrosis and individual cell apoptosis, all these changes were mildly improved by silymarin and ginger treated groups as shown in plate (1).

Table (1): Effect of oral administration of silymarin $(200 \mathrm{mg} / \mathrm{kg} \mathrm{b.wt})$ or ginger $(200 \mathrm{mg} / \mathrm{kg} \mathrm{b.wt})$ for 15 successive days on liver enzyme activities and total bilirubin in normal and paracetamol (500 $\mathrm{mg} / \mathrm{kg} \mathrm{b.wt} \mathrm{for} \mathrm{the} \mathrm{last} 5$ days) induced hepatotoxicity in male albino rats (Mean $\pm \mathrm{SE}$ ) $\mathrm{n}=5$

\begin{tabular}{llrrl}
\hline Groups & $\begin{array}{l}\text { ALT } \\
(\mathrm{U} / \mathrm{L})\end{array}$ & \multicolumn{1}{l}{$\begin{array}{l}\text { AST } \\
(\mathrm{U} / \mathrm{L})\end{array}$} & \multicolumn{1}{l}{$\begin{array}{l}\text { ALP } \\
(\mathrm{U} / \mathrm{L})\end{array}$} & $\begin{array}{l}\text { Total bilirubin } \\
(\mathrm{mg} / \mathrm{dl})\end{array}$ \\
\hline Control & $11.66 \pm 0.881^{\mathrm{d}}$ & $27.00 \pm 2.30^{\mathrm{c}}$ & $83.00 \pm 5.68^{\mathrm{a}}$ & $1.29 \pm 0.069^{\mathrm{c}}$ \\
\hline Silymarin & $11.33 \pm 0.881^{\mathrm{d}}$ & $26.33 \pm 1.20^{\mathrm{c}}$ & $83.00 \pm 1.15^{\mathrm{a}}$ & $1.30 \pm 0.008^{\mathrm{c}}$ \\
Ginger & $12.00 \pm 0.577^{\mathrm{d}}$ & $25.33 \pm 2.33^{\mathrm{c}}$ & $85.33 \pm 4.05^{\mathrm{a}}$ & $1.23 \pm 0.068^{\mathrm{c}}$ \\
Paracetamol & $83.33 \pm 4.25^{\mathrm{a}}$ & $65.66 \pm 2.40^{\mathrm{a}}$ & $88.00 \pm 1.15^{\mathrm{a}}$ & $2.20 \pm 0.035^{\mathrm{a}}$ \\
Silymarin+ Paracetamol & $36.00 \pm 3.05^{\mathrm{c}}$ & $25.33 \pm 4.84^{\mathrm{c}}$ & $83.33 \pm 6.38^{\mathrm{a}}$ & $1.25 \pm 0.056^{\mathrm{c}}$ \\
Ginger+ Paracetamol & $65.66 \pm 2.33^{\mathrm{b}}$ & $51.66 \pm 1.20^{\mathrm{b}}$ & $86.66 \pm 1.45^{\mathrm{a}}$ & $1.73 \pm 0.035^{\mathrm{b}}$ \\
\hline
\end{tabular}

Means within the same column in each category carrying different superscript letters are significant at $\mathrm{P}<0.05$ 
Table (2): Effect of oral administration of silymarin (200 mg/kg b.wt) or ginger (200 mg/kg b.wt) for 15 successive days on serum tumor necrosis factor alpha (TNF- $\alpha$ ) and lactate dehydrogenase (LDH) in paracetamol $(500 \mathrm{mg} / \mathrm{kg}$ b.wt for the last 5 days) induced hepatotoxicity in male albino rats (Mean \pm SE) $n=5$

\begin{tabular}{lll}
\hline Groups & $\begin{array}{l}\text { TNF- } \alpha \\
(\mathrm{pg} / \mathrm{ml})\end{array}$ & $\begin{array}{l}\text { LDH } \\
(\mathrm{U} / \mathrm{L})\end{array}$ \\
\hline Control & $49.52 \pm 2.06^{\mathrm{d}}$ & $165.09 \pm 3.20^{\mathrm{d}}$ \\
Silymarin & $50.59 \pm 0.70^{\mathrm{d}}$ & $168.15 \pm 4.53^{\mathrm{d}}$ \\
Ginger & $50.69 \pm 0.42^{\mathrm{d}}$ & $169.88 \pm 2.48^{\mathrm{d}}$ \\
Paracetamol & $120.38 \pm 4.70^{\mathrm{a}}$ & $257.63 \pm 3.99^{\mathrm{a}}$ \\
Silymarin+ Paracetamol & $69.30 \pm 0.91^{\mathrm{c}}$ & $188.47 \pm 1.27^{\mathrm{c}}$ \\
Ginger+ Paracetamol & $100.42 \pm 3.85^{\mathrm{b}}$ & $226.26 \pm 3.11^{\mathrm{b}}$ \\
\hline
\end{tabular}

Means within the same column in each category carrying different superscript letters are significant at $\mathrm{P}<0.05$

Table (3): effect of oral administration of silymarin (200 mg/kg b.wt) or ginger ( $200 \mathrm{mg} / \mathrm{kg} \mathrm{b.wt)} \mathrm{for}$ 15 successive days on liver antioxidant enzymes activities in paracetamol $500 \mathrm{mg} / \mathrm{kg} \mathrm{b} . \mathrm{wt}$ for the last 5 days) induced hepatotoxicity in albino rats (Mean \pm SE) $n=5$

\begin{tabular}{lllll}
\hline Groups & $\begin{array}{l}\text { CAT } \\
(\mu / g)\end{array}$ & $\begin{array}{l}\text { SOD } \\
(\mu / g)\end{array}$ & $\begin{array}{l}\text { GPX } \\
(\mu / g)\end{array}$ & $\begin{array}{l}\text { MDA } \\
(\mathrm{nmol} / \mathrm{g})\end{array}$ \\
\hline Control & $0.82 \pm 0.081^{\mathrm{a}}$ & $2.60 \pm 0.125^{\mathrm{a}}$ & $114.46 \pm 2.41^{\mathrm{a}}$ & $5.01 \pm 0.195^{\mathrm{d}}$ \\
Silymarin & $0.85 \pm 0.055^{\mathrm{a}}$ & $2.36 \pm 0.317^{\mathrm{a}}$ & $115.46 \pm 2.96^{\mathrm{a}}$ & $5.03 \pm 0.110^{\mathrm{d}}$ \\
Ginger & $0.86 \pm 0.045^{\mathrm{a}}$ & $2.50 \pm 0.149^{\mathrm{a}}$ & $111.34 \pm 7.19^{\mathrm{a}}$ & $5.04 \pm 0.039^{\mathrm{d}}$ \\
Paracetamol & $0.24 \pm 0.032^{\mathrm{d}}$ & $0.55 \pm 0.031^{\mathrm{b}}$ & $51.84 \pm 2.54^{\mathrm{d}}$ & $22.30 \pm 1.89^{\mathrm{a}}$ \\
Silymarin+ Paracetamol & $0.62 \pm 0.044^{\mathrm{b}}$ & $1.72 \pm 0.146^{\mathrm{a}}$ & $97.95 \pm 1.52^{\mathrm{b}}$ & $7.45 \pm 0.407^{\mathrm{c}}$ \\
Ginger+ Paracetamol & $0.37 \pm 0.031^{\mathrm{c}}$ & $1.51 \pm 0.124^{\mathrm{a}}$ & $65.37 \pm 2.73^{\mathrm{c}}$ & $12.86 \pm 1.06^{\mathrm{b}}$ \\
\hline
\end{tabular}

Means within the same column in each category carrying different superscript letters are significant at $\mathrm{P}<0.05$ 


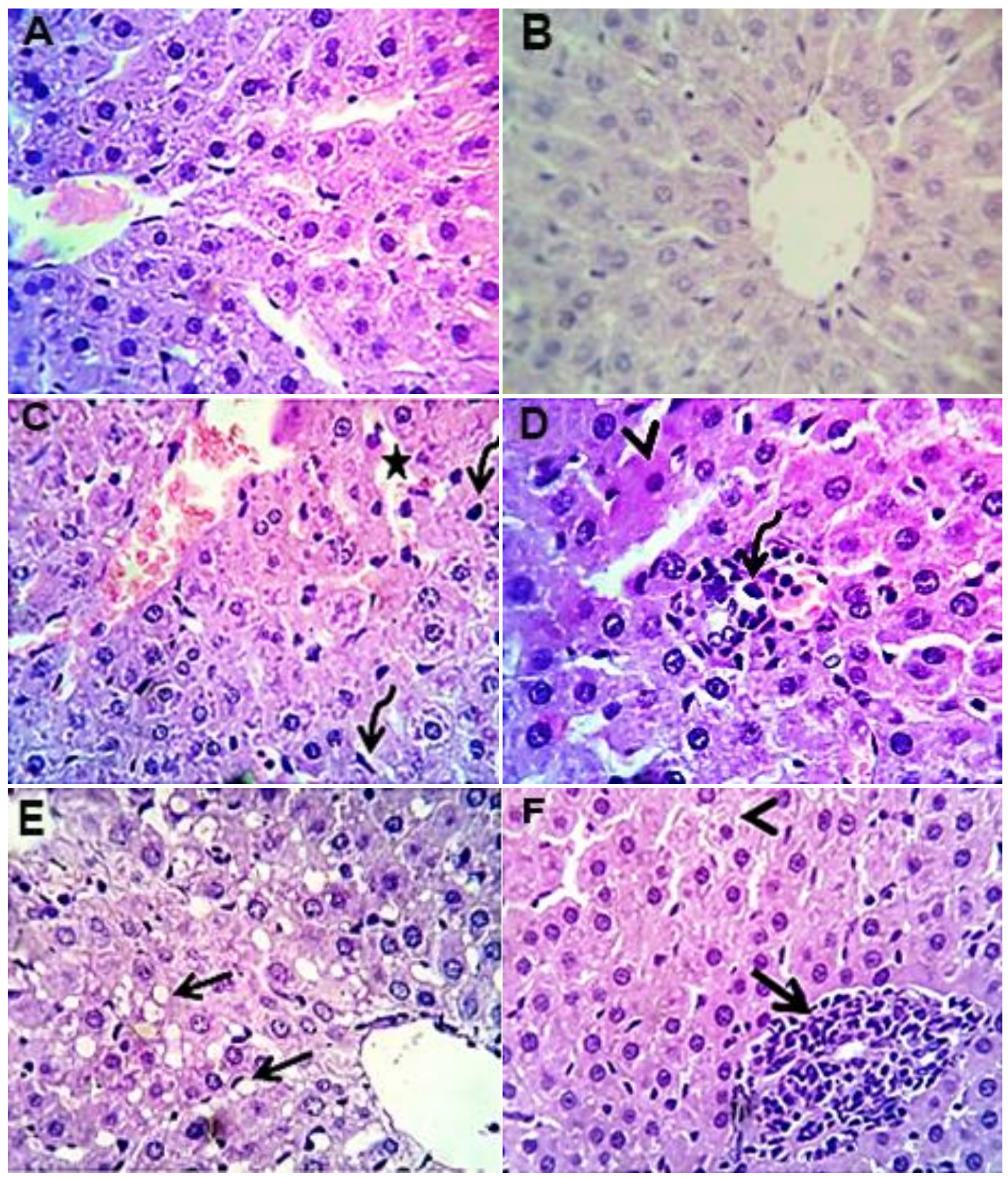

Plate 1. Photomicrographs of rat liver sections in the different experimental groups stained with

$\mathrm{H} \& \mathrm{E}$ x 400.

A, B and C: Rats liver sections in control, silymarin and ginger group respectively revealed normal hepatic histomorphological structures with prominent Kuppfer cells (curved arrows) and mildly dilated hepatic sinusoids (star) in C (ginger group). D: Rats liver section in paracetamol treated group showed mild biliary proliferation, focal necrosis, individual cells apoptosis (arrowhead) and lymphocytosis in hepatic sinusoids (curved arrow). E: Liver section in silymarin and paracetamol treated group exhibited apparently normal hepatic parenchyma with mild to moderate centrilobular vacuolation (fatty changes) (arrows). F: Liver section in ginger and paracetamol treated group revealed round cells aggregation in portal area (arrow) with degenerative changes in a few hepatocytes (arrowhead). Generally there was improvement in silymarin and paracetamol treated group and also in ginger and paracetamol treated group. 


\section{DISCUSSION}

Various medicinal plants have been evaluated for their potential effects as hepatoprotective agent (Ahmed and Khater 2001 and Kumar et al., 2004). In the current investigation, an attempt was made to reduce the hepatotoxic impact of paracetamol by using ginger as a medical prophylactic plant. PCM induced-hepatocellular damage is mediated through its reactive metabolite, namely NAPQI which cause acute centrilobular hepatic necrosis that lead to loss of cell function and structural integrity of hepatocellular membrane (Lee et al., 1996). It has been outstanding that enzyme AST and ALT are markers of hepatocyte alterations and abnormal level of AST and ALT is a critical marker for the liver damage (Mcgill and Jaeschke, 2013). In this study, paracetamol prompted hepatic damage in rats by elevation the activities of ALT and AST in serum. Our outcomes are in agreement with Tung et al. (2017) who mentioned that administration of paracetamol $(500 \mathrm{mg} / \mathrm{kg}$ b.wt) to mice produced higher activities of ALT and AST in serum.Also this study agreed with Elkomy et al .(2016) who stated that oral administration of paracetamol $(1 \mathrm{~g} / \mathrm{kg} \mathrm{b.wt})$ caused a significant increase in liver parameters (ALT ,AST and bilirubin levels). In the current study, administration of silymarin or ginger prior and simultaneously with paracetamol return close the elevated serum ALT and AST levels to normal levels. These findings are reliable with Hamid et al. (2011) who demonstrated that concurrent administration of Zingiber zerumbet at $200 \mathrm{mg} / \mathrm{kg}$ and $400 \mathrm{mg} / \mathrm{kg}$ with $750 \mathrm{mg} / \mathrm{kg}$ PCM for seven progressive days was able to suppress PCM induced hepatocellular injury as evidenced by the significant reduced in the levels of serum hepatic enzymes. The present study reported a significant elevation in serum total bilirubin in rats orally received PCM. Hyperbilirubinemia may result from the creation of more bilirubin than the liver can process and harm to the liver may weaken its capacity to discharge normal amounts of bilirubin. Serum bilirubin is one of genuine trial of liver capacity because it reflects to what extent the liver ready to take bilirubin and process it into bile (Jaeschke et al., 2003). Raised total serum bilirubin level observed in PCM hepatotoxic rats suggested abnormal conjugation of bilirubin by the liver because generalized hepatocellular harm (El-Sherbiny et al., 2003). The current study revealed a significant reduction in total serum bilirubin level which was resulted from administration of ginger extract prior and simultaneously with PCM. The reduction in complete total serum bilirubin recorded in this investigation was reported by previous works (Ozougwu et al., 2016). The possible mechanism of action of Zingiber officinale on diminishing aggregate serum total bilirubin might be through their cell reinforcement impacts, since Zingiber officinale has active ingredients that are capable of free radical scavenging in living framework (Mitra et al., 1998).

The findings showed a significant rise in TNF- $\alpha$ level and LDH enzyme activity following paracetamol administration. These findings are in concern with Farghaly and Hussein (2010) who stated that oral administration of PCM $(500 \mathrm{mg} / \mathrm{kg}$ b.wt) for the last 5 successive days of the investigation to rats revealed a marked elevation in serum TNF- $\alpha$ and LDH. The recorded results demonstrated that administration of silymarin or ginger extract before and simultaneously with PCM elicited a significant decline in TNF- $\alpha$ level and LDH enzyme activity. Atomic investigations have likewise demonstrated that ginger decreased the raised 
TNF- $\alpha$ in rats with liver cancer, suggesting that the showed chemopreventive impacts may be mediated through the inhibiting effects on nuclear factor Kappa-light-chain-Enhancer of activated $\mathrm{B}$ cells $\left(\mathrm{NF}_{\mathrm{k}} \mathrm{B}\right)$, possibly through the suppression of the proinflammatory TNF- $\alpha$ (Habib et al., 2008). The present results agreed with Ozougwu et al. (2016) who reported that oral administration of Zingiber officinale extracts at doses (200, 300 and $450 \mathrm{mg} / \mathrm{kg}$ ) showed a reduction in LDH enzyme activity of paracetamol hepatotoxic rats after term of the investigation (12 weeks) and this support our study. The outcomes exhibited a critical decrease in CAT, SOD and GPX enzymes activities in PCM treated rats and high rising in MDA concentration. These findings are in harmony with Almajwal and Elsadek (2015) who found that administration of PCM resulted in a significant elevation of the hepatic tissue MDA (a biochemical marker of lipid peroxidation) concentration while antioxidant enzymes such as CAT, SOD and GPX have been significantly reduced. The same was noticed by Tung et al. (2017) who explored that rats received $500 \mathrm{mg} / \mathrm{kg}$ b.wt of paracetamol for 7 days exhibited a significant increase in MDA concentration. The rise in the MDA concentration of liver demonstrates enhanced lipid peroxidation prompting tissue injury and failure of the antioxidant defense mechanisms to prevent the formation of excess free radicals (Nimila et al., 2016).

The present study showed that administration of silymarin or ginger extract before and simultaneously with PCM elicited a significant increase in CAT, SOD and GPX activities with a reduction in MDA level. These results agreed with Kumar et al. (2011) who observed that treatment of PCM intoxicated rats with silymarin $(100 \mathrm{mg} / \mathrm{kg})$ orally for 10 days caused a significant reduction in the hepatic MDA level and enhanced the antioxidant enzymes (CAT, SOD and GPX). Also, our findings correspond with the results of Hamid et al. (2011) who mentioned that administration of ethryl acetate extract of Zingiber zerumbt at doses of 200 and $400 \mathrm{mg} / \mathrm{kg}$ b.wt for 7 days protected the rats from PCM hepatotoxicity by inhibition of hepatic MDA elevation and restoring the antioxidant enzymes.

In the present study, the histopathological findings of liver sections of rats induced hepatotoxicity with paracetamol exhibited a moderate congestion of hepatic blood vessels, degenerative and necrotic changes in a mild to moderate number of hepatic cells (25-30\%), portal aggregation of round cells and mild biliary proliferation in addition to focal individual cells necrosis and apoptosis with replacement of the dead cells with round cells could be detected also the hepatic sinusoids showed mild to moderate lymphocytosis and Kupffer cells were moderately enlarged. The recorded results are in agreement with Bektur et al. (2016) who found that liver of female mice received paracetamol $(500 \mathrm{mg} / \mathrm{kg}$ single dose orally for 7 days) showed severe histological changes in liver including necrosis, swelling of hepatocytes, vascular congestion and dilatation also the study elicited mononuclear cell infiltration and apoptosis.

\section{CONCLUSION}

In conclusion the findings of this study exhibit that ginger extract was sutable for anti-paracetamol induced hepatic damage in rats. Ginger extract produces a remarkable hepatoprotective effect in paracetamol-treated rats.

\section{REFERENCES}

Aebi H. 1984. Catalase in-vitro. In: Packer L, editor. Methods of Enzymology. Vol. 105. San Diego: Academic Press Incpp., 121-126.

Ahmed M.B., Khater M.R. 2001. Evaluation of the protective potential of Ambrosia maritima extract on acetaminophen- 
induced liver damage. Journal Ethnopharmacology, 75: 169-174.

Ajith T.A., Nivitha V., Usha S. 2007. Zingiber officinale Roscoe alone and in combination with a-tocopherol protect the cisplatin -induced acute renal failure . Food and Chemical Toxicology. 45: 921-927.

Almajwal A.M., Elsadek M.F. 2015. Lipidlowering and hepatoprotective effects of Vitis viniferadried seeds on paracetamol-induced hepatotoxicity in rats. Nutrition Research and Practice. 9 (1): $37-42$.

Bancroft, J.D., Gamble, M. 2013. Theories and Practical of Histopathological Techniques. $\quad 6^{\text {th }}$ Ed., Chirchill Livingstone, New York, London, Madrid.

Bektur N.E., Sahin E., Baycu C., Ubver G. 2016. Protective effect of silymarin against acetaminophen-induced hepatotoxicity and nephrotoxicity in mice. Toxicology and Industrial Health, 32 (4): 589-600.

Corti A., Fassino J., Marcucci F., Barbenti E., Cassani G. 1992. Oligometric tumor necrosis factor- $\alpha$ slowly converts into the reactive forms at bioactive levels. Biochemical Journal , 284: 905-910.

Doumas B.T., Perry B.W., Sasse E.A. 1973. Standardization in bilirubin assays: Evolution of selected method and stability of bilirubin solution. Clinical Chemistry, 19: 984-993.

Elkomy A., Aboubakr M., Soliman A., Abdeen A., Abdelkader A., Hekal H., 2016 : paracetamol induced hepatic toxicity and amelioration by cinnamon in rats .International Journal of Pharmacology and Toxicoloy,4(2) 187190 .

Elmowafy M., Viitala T., Ibrahim H.M. 2013. Silymarin loaded liposomes for hepatic targeting: in vitro evaluation and
HepG2 drug uptake. European Journal of Pharmaceutical Sciences, 50 (2): 161-171.

El-Sherbiny E.A., Abd-Allah G.A., Goneim S.T. 2003. Relationship of liver function tests to different stages of chronic liver diseases in HCV carriers. Journal Egyptian Germany Social of Zoology Comp. Physiology., 40: 71-93.

El-Shitanya N.A., El-Haggarb S., El-Desoky K. 2008 Silymarin prevents adriamycininduced cardiotoxicity and nephrotoxicity in rats. Food and Chemical Toxicology, 46: 2422-2428.

Farghaly H.S., Hussein M.A. 2010. Protective effect of curcumin against paracetamolinduced liver damage. Australian Journal of Basic and Applied Sciences, 4 (9): 4266-4274.

Gulcin I. 2006. Antioxidant activity of caffeic acid (3,4-dihydroxycinnamic acid). Toxicology. 217: 213-220.

Habib S.H., Makpol S., Abdul Hamid N.A., Das S., Ngah W.Z. 2008. Ginger extract (Zingiber officinale) has anti-cancer and anti-inflammatory effects on ethionineinduced hepatoma rats. Clinics (Sao Paulo), 63: 807-813.

Hamid A., Budin S.B., Mohamed R.A.P., Abd Manaf N., Yuhana N. Y., Husain K., Abd Hamid Z., Mohamed J. 2011. Role of oxidative stress in the protective effects of Zingiber Zerumbet Smith ethyl acetate extract against paracetamol-induced hepatotoxicity in sprague-Dawley rats. Australian Journal of Basic and Applied Sciences, 5 (8): 1519-1525.

Jaeschke H., Knight T.R., Bajt M.L. 2003. The role of oxidant stress and reactive nitrogen species in acetaminophen hepatotoxicity. Toxicology Letters, 144 (3): 279-288.

Jayadevaiah K.V., Bhat K.I., Joshi A.B., Vijaykumar M., Rawal P. 2012. 
Hepatoprotective activity of

Desmodium oojeinense (Roxb.) H.

Ohashi against paracetamol induced toxicity. Asian Journal Pharm Health Sciences, 2:312e315.

Kanchanai N., Sadiq A.T.M. 2011. Hepatoprotective effect of Plumbago Zeylanica on paracetamol induced liver toxicity in rats. International Journal of Pharmacy and Pharmaceutical Sciences, 3 (1): 151-154.

Khaki A.A., Khaki A. 2010. Antioxidant effect of ginger to prevents leadinduced liver tissue apoptosis in rat, Journal Medicinal Plants Researches, 4: 1492-1495.

Kumar G., Banu G.S., Pappa P.V., Sundararajan M., Pandian M.R. 2004. Hepatoprotective activity of Trianthema portulacastrum L.against paracetamol and thioacetamide intoxication in albino rats. Journal Ethnopharmacol., 92: 3740.

Kumar M.R., Phaneendra P., Bodhanapu S., Fasalu R.O.M., Mohamed O.K., Tamizmani T. 2011. Antioxidant and hepatoprotective activity of the aqueous extract of Myrtus Communis (Myrtle) Linn. Leaves. Pharmacology online, 1: 1083-1090.

Lancaster E.M., Hiatt J.R., Zarrinpar A. 2015. Acetaminophen hepatotoxicity: an update review. Arch. Toxicolology, 89: 193-199.

Larson A.M. 2007. Acetaminophen hepatotoxicity. Clinical Liver Diseases , 11: 525-548.

Lee S.S., Buters J.T., Pineau T., FernandezSalquero P., Gonzalez F.J. 1996. Role of CYP2E1 in hepatotoxiciy of acetaminophen. Journal Biolological Chemistry, 271: 12063-12067.

Mandade R.J. 2011. Hepatoprotective activity of ethanolic extract of Caesalpinia bonduc (L.) in paracetamol intoxicated albino rats. International Journal of Pharm Tech Research 2011; 3 (1): 431434.

Mcgill M.R., Jaeschke H. 2013. Metabolism and disposition of acetaminophen: recent advances in relation to hepatotoxicity and diagnosis. Pharmaceutical Researches, 30 (9): 2174-2187.

Mitra S.K., Venkataranganna M.V., Sundaram R., Gopumadhavan S. 1998. Effect of HD-03, a herbal formulation, on the antioxidant defense system in rats. Phytology Researches, 12: 114117.

Moss D.W. 1982. Alkaline Phosphatase isoenzymes. Clinical Chemistry, 28 (10): 2007-2016.

Nimila I.C., Lalitha K.G., Sekar V., Sambathkumar R., Jayaseelan S., Devi P. 2016. Hepatoprotective Effect and In Vivo Antioxidant Activity of Stem Barks of Hibiscus vitifolius Linn against Paracetamol Induced Hepatotoxicity in Rats. International Journal Pharmaceutical Sciences Researches., 41(1): 223-228.

Nishikimi M Roa N.A., Yogi K. 1972. Measurement of superoxide dismutase. Biochpa.Biochemical Bioph. Reseaches Common., 46:849-854.

Ohkawa H., Oshishi N., Yagi K. 1979. Assay for lipid peroxidase in animal tissues by thiobarbituric acid reaction. Analytical Biochemistry , 95 (2): 351-358.

Ozougwu J.C., Elom M.O., Obimba K.C., Obiukwu C.E., Usanga V.U. 2016. Ameliorative effects of Zingiber officinale extracts against experimentally-induced hepatotoxicity in rats. American Euras. Journal Toxicolological Sciences, 8 (2): 69-76.

Paglia D.E., Valentine W.N. 1967. Studies on the quantitative and qualitative characterization of erythrocyte 
glutathione peroxidase. Journal Labaratory Clinical Medicin , 70 (1): 158-169.

Patel N., Joseph C., Corcoran G.B., Ray S.D. 2010. Silymarin modulates doxorubicin-induced oxidative stress, $\mathrm{Bcl}-\mathrm{xL}$ and $\mathrm{p} 53$ expression while preventing apoptotic and necrotic cell death in the liver. Toxicology and Applied Pharmacology, 245: 143-152.

Rajkiran K., Eswar Kumar K., Satyanarayana S. 2015. Evaluation of in vitro antioxidant activity of aqueous extract of root of Coleus edulis and its correlation with in vivo hepatoprotective activity in paracetamol induced hepatotoxicity in rats. Asian Journal Pharmaceutical, Clinical Reseaches. 8 (4): 56-61.

Reitman S., Frankel S. 1957. Colorimetric method for determination of serum transaminases activities. American Journal Clinical Pathology , 28:56-68.

Satoh K. 1978. Serum lipid peroxide in cerebrovascular disorders determined by new colorimeteric method. Clinical Chimical Acta., 37-43.

Sekhar M.D., Rajkumar M., Saradindu B., Koushik D., Debidas G. 2005. Protective Effect of Composite Extract of Withania somnifera, Ocimum sanctum and Zingiber officinale on Swimming-Induced Reproductive Endocrine Dysfunctions in Male Rat, International Journal Phamacetical Researches, 4:110-117.

Shanmugasundaram P., Venkataraman S. 2006. Hepatoprotective and antioxidant effects of Hygrophila auriculata (K. Schum Heine Acanthaceae root extract). Journal of Ethnopharmacology, 104 (12): 124-128.

Siekman L., Bonora R., Burtis C.A., Ceriotti F., Clero-Renaud P., Ferard G. 2002. IFCC primary reference procedures for the measurement of catalytic activity concentrations of catenzymes at 37 degrees C. Part 3. Reference procedure for the measurements of catalytic entration of lactate dehydrogenase. Clinical Chemical Lab Medicin, 40 (6): 643-648.

Tamhane A.C., Dunlop D.D. 2000. Statistics and data analysis from elementary to intermediate. Upper Saddle River, USA.

Tung B.T., Hai N.T., Son P.K. 2017. Hepatoprotective effect of Phytosome Curcumin against paracetamol-induced liver toxicity in mice. Brazilian Journal Pharmaceutical Sciences , 53 (1): 16136-16149.

Zancan K.C., Marques M.O., Petenate A.J., Miereles M.A. 2002. Extraction of ginger oleoresin with $\mathrm{coz}$ and cosolvents: A study of antioxidant action of the extracts, Journal Supercit Flu., 24: 57-76. 